\title{
The effect of Telmisartan versus Cilnidipine on memory and psychomotor functions in patients with essential hypertension - An open label, randomized, parallel comparative study
}

\author{
DEBASIS BISOI ${ }^{1}$ and Donepudi Aruna ${ }^{2}$ \\ ${ }^{1}$ Kalinga Institute of Medical Sciences \\ ${ }^{2}$ Nizam's Institute of Medical Sciences
}

April 27, 2020

\begin{abstract}
Introduction: Hypertension is a global public health issue. Data on the effect of Anti- hypertensive drugs on dementia, Alzheimer's disease, cognitive impairment is limited and inconclusive. Material and Methods: It was a Prospective, randomized, open label, comparative study. Total 60 hypertensive Patients were randomized to receive either Telmisartan or Cilnidipine. Memory functions were evaluated with PGI Memory Scale, while psychomotor functions were evaluated with Six Letter Cancellation test (SLCT) and Digit Letter Substitution test (DLST) and card sorting test (CST). Student t-test was used to compare the means of test scores between and within the groups. Statistical significance was considered at $\mathrm{P}<0.05$. Results: An improvement was observed in scores of memory in both the groups which was not significant. A significant improvement $(\mathrm{p}<0.05)$ was shown in 3 of 10 subtests of memory in Telmisartan group compared to Cilnidipine. Both the drugs showed significant improvement in psychomotor function tests $(\mathrm{P}<0.05)$. SLCT score was $40.33 \pm 1.58$ (CI 38.8 - 42) in Cilnidipine group and $38.80 \pm 1.56$ (CI 37.2 - 40.4) in Telmisartan group. Cilnidipine showed significant improvement in SLCT and DLST scores compared to Telmisartan. Both the study drugs decreased BP significantly $(\mathrm{P}<0.01)$. Conclusion: Both Telmisartan and Cilnidipine showed no change in memory and significant improvement in psychomotor functions in newly diagnosed Stage - I essential hypertension patients. But Telmisartan showed more improving trends in memory than Cilnidipine. Cilnidipine significantly improved psychomotor functions compared to Telmisartan. Further randomized controlled studies are needed to establish these effects.
\end{abstract}

The effect of Telmisartan versus Cilnidipine on memory and psychomotor functions in patients with essential hypertension - An open label, Randomized, parallel, comparative study

\section{Summary}

Introduction: Hypertension is a global public health issue. Data on the effect of Anti- hypertensive drugs on dementia, Alzheimer's disease, cognitive impairment is limited and inconclusive.Material and Methods: It was a Prospective, randomized, open label, comparative study. Total 60 hypertensive Patients were randomized to receive either Telmisartan or Cilnidipine. Memory functions were evaluated with PGI Memory Scale, while psychomotor functions were evaluated with Six Letter Cancellation test (SLCT) and Digit Letter Substitution test (DLST) and card sorting test (CST). Student t-test was used to compare the means of test scores between and within the groups. Statistical significance was considered at $\mathrm{P}<0.05$. Results: An improvement was observed in scores of memory in both the groups which was not significant. A significant improvement $(\mathrm{p}<0.05)$ was shown in 3 of 10 subtests of memory in Telmisartan group compared to Cilnidipine. Both the drugs showed significant improvement in psychomotor function tests $(\mathrm{P}<0.05)$. SLCT score was $40.33 \pm 1.58$ (CI 38.8 - 42) in Cilnidipine group and $38.80 \pm 1.56$ (CI 37.2 - 40.4) in Telmisartan group. Cilnidipine showed significant improvement in SLCT and DLST scores compared to Telmisartan. Both the 
study drugs decreased BP significantly $(\mathrm{P}<0.01)$.Conclusion: Both Telmisartan and Cilnidipine showed no change in memory and significant improvement in psychomotor functions in newly diagnosed Stage - I essential hypertension patients. But Telmisartan showed more improving trends in memory than Cilnidipine. Cilnidipine significantly improved psychomotor functions compared to Telmisartan. Further randomized controlled studies are needed to establish these effects.Introduction Hypertension is a global public health issue. The prevalence of hypertension increases with age. It causes progressive pathological changes in the cardiovascular and central nervous system. The complications arising are stroke [1], vascular dementia [2] and probably Alzheimer's disease [3]. Studies have shown that hypertension is the most important pathological factor for poor cognitive function $[4,5,6]$. Uncontrolled hypertension may lead to cognitive decline [7].

Several prospective studies have indicated that use of antihypertensive drugs may reduce the risk of dementia $[8,9,10]$, whereas other studies showed no association between Hypertension and dementia [11,12]. First line treatment for hypertension according to Joint National Committee on Prevention, Detection, Evaluation and Treatment of High Blood Pressure (JNC- 8) algorithm is Angiotensin Converting Enzyme (ACE) inhibitors, Angiotensin (ATII) receptor antagonists (ARBs), Diuretics and Calcium Channel Blockers (CCBs) [13].

The effect of several antihypertensive drugs on cognitive function has been studied. Clinical trials evaluating antihypertensive drugs indicated two antihypertensive drug classes in the prevention of cognition decline and dementia in patients with hypertension, independent of blood pressure (BP) decrease. They are Dihydropyridine calcium-channel blockers (CCBs) as shown in the Syst - Eur trial [14] and Angiotensin - 1 receptor blockers (AT - 1 blockers) $[15,16]$. Other studies have also shown better improvement in cognition with Angiotensin converting enzyme (ACE) inhibitors and Angiotensin - II (AT-II) receptor antagonists $[17,18,19]$.

Among the ARBs, Telmisartan, Losartan, Candesartan and valsartan had shown beneficial effects on memory and psychomotor functions. Telmisartan was compared with Olmesartan [20] and losartan [21] for cognitive and psychomotor functions. In these studies, Telmisartan was found to be as effective as losartan and better than Olmesartan in improving cognitive functions. In another study, Telmisartan was compared with Atorvastatin. In this study Telmisartan showed better improvement in psychomotor function compared to atorvastatin [22].

CCBs mitigated the negative effects of the presence of APOE-4 alleles on cognitive decline. Treatment with Nifedipine led to a significant fall in levels of A $\beta 1-42$, with no significant decrease in cell viability. CCBs (Nitrendipine, Cilnidipine and Nilvadipine) promoted A $\beta 1$ - 42 clearance across the blood brain barrier in wild type mice. Nilvadipine improved the cognitive functions of the animals in Morris water maze test, when treated with human A $\beta 1$ - 42. These studies clearly suggest that DHP CCBs possess non-channelling functions that are independent of their calcium channel blocking ability, suggesting a need for thorough validation of CCBs for AD [23]. Data from these studies suggest that use of CCBs significantly diminishes the rate of progression to dementia and may minimize formation of A $\beta 1-42$ [24]. The effect of CCBs on dementia has mainly been studied using a number of dihydropyridine molecules that have originally been developed for the treatment of hypertension. Most clinical trials focused on Nimodipine and Nilvadipine as they cross blood brain barrier effectively [25]. In one study two calcium channel blockers from the class of dihydropyridines were examined side by side: Nilvadipine and Amlodipine. Patients having mild cognitive impairment were treated with Nilvadipine and cognition did not deteriorate for 20 months. Meanwhile, amlodipine treatment did not seem to be protective. However, both treatments lowered Blood Pressure to the same extent, indicating that the protective effect was independent from the antihypertensive effect [26]. However, data on the effect of antihypertensive drugs on dementia, Alzheimer's disease, cognitive impairment, and cognitive decline are limited and inconclusive.

Cilnidipine is a unique $\mathrm{Ca} 2+$ channel blocker possessing inhibitory action on the sympathetic N-type Ca2+ channels along with L-type. Cilnidipine also increases insulin sensitivity [27]. It will be more helpful to the patients with hypertension and Diabetes, if it improves cognition also. Hence, we have compared Telmisartan with Cilnidipine in this study to evaluate their effect on memory and psychomotor functions in patients with 
essential hypertension.

Material and Methods

The present study was conducted in the Department of Clinical Pharmacology and Therapeutics, in collaboration with Department of Medicine, Nizam's Institute of Medical Sciences, Hyderabad, Telangana, India. Study was conducted between September 2017 to October 2018. It was an open labelled, Prospective, randomized, parallel, comparative study. Sample size was 60 patients with essential hypertension, 30 in each group. Inclusion criteria were 1 . Patients aged between 18 to 55 years of either gender willing to give written informed consent 2. Newly diagnosed patients with stage - I essential hypertension (systolic BP 140-159 mm of $\mathrm{Hg}$ or diastolic BP 90-99 mm of $\mathrm{Hg}$ ) 3. Patients able to comprehend and perform the tests and comply with all study procedures Exclusion criteria were patients with secondary hypertension, History of hypersensitivity or drug allergy, patients with hypertensive retinopathy, patients with a history of hypertensive encephalopathy or cerebrovascular accident, patients with Type-I diabetes mellitus or patients with diabetes mellitus who are on insulin therapy, Patients with previous or current heart failure; myocardial infarction; angina pectoris, valvulopathy or clinically relevant arrhythmias, patients with impaired hepatic or renal function, patients with clinically relevant hypo- or hyperthyroidism, patient with neuropsychiatric diseases (depression, Parkinsonism, Alzheimer's disease), patients who are prescribed drugs that could affect cognitive functions, pregnant and lactating women. Approval was taken from NIMS Institutional Ethics Committee. The study was conducted according to ICH-GCP guidelines and declaration of Helsinki. Written informed consent was taken from all the study subjects. All the eligible patients were trained for psychomotor functions before study on 3 different occasions. They were asked to abstain from smoking and caffeine intake for at least 10 hours and alcohol intake for 48 hours before the study procedure. On the study day (Day zero) vital parameters of the study subjects were measured. Baseline memory and psychomotor function tests were conducted. The patients were randomized to either Telmisartan $40 \mathrm{mg}$ or Cilnidipine $10 \mathrm{mg}$ once daily. Randomization was done using random tables. Patients with Type -2 Diabetes Mellitus were allowed to continue oral antidiabetic medication Metformin and Sulphonyl urea group drugs. After one month, the patients in whom, Blood Pressure (BP) did not lower satisfactorily to the study drugs, were excluded from the study. Duration of treatment was 3 months. Patients were asked for follow up visits were at 1 and 3 months. At each visit, body weight and sitting BP were measured and memory and psychomotor functions were assessed. Compliance was assessed by pill count method. Patients were considered compliant when more than $80 \%$ of drug used, in more than $80 \%$ of days. Primary outcomes were changes in memory scores and psychomotor function test scores from baseline to the end of the study (3 months) in both the study groups. Secondary outcomes were 1. Change in blood pressure from the baseline to the end of the study 2 . Change in body weight from the baseline to the end of the study 3. Adverse reactions reported in both the groups. Psychomotor function tests comprise six letter cancellation test, digit letter substitution test, card sorting test. For memory testing Post Graduate Institute, Chandigarh, Memory Scale (PGIMS) was used $[28,29]$. It is a uniquely designed test for evaluation of memory in semi-literate people suitable for the Indian population. It comprises of $10 \mathrm{sub}$ - tests to measure different components of memory (remote and recent memory, mental balance, attention and concentration, delayed and immediate recall, verbal retention of similar and dissimilar pairs, visual retention and recognition of common objects). Total score for these tests is 100. Statistical analysis: Data was presented as mean \pm SE. Normality of distribution of data was analysed by Shapiro Wilkes test. Unpaired t-test was used to compare the means of Memory test scores between the groups and paired t test within the groups. The incidence of adverse drug reaction between the groups was analysed by Chi square test. The level of significance was $5 \%$ i.e. $\mathrm{P}<0.05$.

\section{Results}

In the present study, a total of 76 patients were screened. Ten patients were excluded because four patients had secondary hypertension, three patients did not wish to participate in the study and three patients were not able to comprehend the tests for memory and psychomotor assessment. In the Telmisartan group 33 patients were enrolled. Out of 33 participants one participant discontinued the study due to personal reasons and two discontinued the treatment. In the Cilnidipine group 33 patients were enrolled. Out of 33 participants two discontinued the treatment and one patient was lost to follow up. So in final analysis 60 participants 
were evaluated, 30 in each group (Figure - 1). No patient was disqualified due to non-response to study drugs at one month. Thirty-five were males and 25 were females. The mean age of patients was $45.13 \pm 5.2$ years. Demographic data is given in table - 1.Primary Outcomes: 1. Effects on Memory:Remote Memory and Recent memory scores: There was a significant improvement in Telmisartan group $(\mathrm{p}<0.05)$ in remote and recent memory scores at the end of study compared to baseline. The mean percentage increase of remote memory score was $5.53 \%$ and in recent memory was $3.66 \%$. No significant improvement was observed in Cilnidipine group. The mean percentage increase of remote memory score was $5.21 \%$ and was $2.82 \%$ after three months. The actual values were given in Table - 2. There was no significant improvement in remote and recent memory scores between Telmisartan and Cilnidipine groups.Mental balance scores: There was no significant improvement in mental balance scores at the end of the study in both study groups as well as between the groups (Table - 2).Attention and concentration scores: Both the study groups showed a significant $(\mathrm{p}<0.05)$ improvement in attention and concentration score after three months compared to baseline. The mean percentage increase was $4.95 \%$ in Telmisartan group and $4.86 \%$ in Cilnidipine group. No significant improvement in was observed between Telmisartan and Cilnidipine group at three months (Table 2 ).Visual retention test: There was an improvement in visual retention score in Cilnidipine group (0.86\%) after three months, which was statistically not significant. In Telmisartan group, a decrease of visual retention score $(1.79 \%)$ was observed at the end of the study, which was also not statistically significant (Table - 2). Cilnidipine significantly $(\mathrm{P}<0.05)$ improved Visual retention score when compared to Telmisartan at the end of study (Figure - 2). No significant improvement was observed in delayed recall, Immediate recall, verbal retention of similar pairs, verbal retention of dissimilar pairs and Visual Recognition scores at the end of the study in both the study groups as well as between the groups (Table - 2).

\section{Effects on Psychomotor function tests:}

Both the study groups showed Significant $(\mathrm{p}<0.01)$ improvement in the in six letter cancellation test (SLCT) and card sorting test (CST) scores after 3 months compared to baseline. The mean percentage increase of SLCT score was $5.63 \%$ in Telmisartan group and $8.41 \%$ in Cilnidipine group. The mean percentage decrease of CST score was $6.73 \%$ in Telmisartan group and $5.57 \%$ in Cilnidipine group. A significant $(\mathrm{P}<0.01)$ improvement in SLCT and no improvement in CST was observed in Cilnidipine group when compared to Telmisartan group (Table - 3). There was no significant improvement in both the study groups in DLST at the end of the study. But a significant $(\mathrm{P}<0.05)$ improvement was observed in Cilnidipine group at the end of the study compared to Telmisartan group (Table - 3). Secondary Outcomes:

Both the study drugs decreased the systolic and diastolic BP significantly $(\mathrm{P}<0.01)$. The mean percentage decrease in systolic BP was $9.96 \%$ and in diastolic BP was $6.49 \%$

in Telmisartan group and $10.6 \%$ and $5.21 \%$ respectively in Cilnidipine group (Table - 4) (Figure - 3). The decrease in BP was not significant when compared between groups.

Both the study drugs decreased the body weight significantly at the end of the study. The mean percentage decrease of body weight was $1.44 \%$ in Telmisartan group and $1.27 \%$ in Cilnidipine group. No significant decrease in Body weight was found when compared between the groups. There were no serious adverse events reported in any of the study participants. In Telmisartan group one patient had complaint of nausea, one patient complained of light headedness. In Cilnidipine group one patient had complaint of ankle swelling and one patient had complaint of headache. No one stopped treatment because of side effects.Discussion This study evaluated the effect of two antihypertensive drugs - Cilnidipine and Telmisartan on memory and psychomotor function test on patients, newly diagnosed with stage I hypertension. The memory function of participants was analysed by using PGI memory test [28] which contain 10 different items. This is a standardized and validated test applicable for Indian population. The battery of tests contains test for memory, recall, mental balance, attention and concentration verbal retention, visual retention and visual recognition of objects. The psychomotor function tests used were three simple tests by using pencil and paper. The tests were six letter cancellation test, digit letter substitution test and card sorting test. These tests were developed and validated at our department. In our study, we did not get significant improvement in remote and recent memory scores compared between Telmisartan and Cilnidipine. 
But there was a significant increase in remote and recent memory scores in the Telmisartan group compared to baseline. Our results were consistent with the previous studies [20,30,31]. Kavitha et al [20] compared Telmisartan with Olmesartan in 101 hypertensive patients. They also could not find significant improvement in remote and recent memory scores between the groups. Fogari et al [30] compared Losartan with Atenolol in 120 hypertensive patients on memory function. The duration in this study was 6 months. They concluded that losartan group had a significant improvement in both recent and remote memory tests at the end of the study and Losartan showed significant improvement in both memory tests compared to Atenolol. Another study [31] proved that Telmisartan was associated with an improvement in cognitive functions compared to Lisinopril in metabolic syndrome patients after 12 weeks. A meta-analysis [32] showed that ARBs can enhance cognitive functions in the elderly, especially episodic memory. Though ACE-Is, diuretics, BBs and CCBs did not seem to boost cognitive function in the elderly but were similarly effective to reduce blood pressure as ARBs. This indicated that AT 1 receptor blockers are better than other antihypertensive drugs in enhancing memory and cognition in these patients. There was a significant increase in attention and concentration scores in both the study groups compared to baseline. But no significant improvement was found when compared between the groups. Our results are in correlation with the results of previous studies [20,21]. We did not get significant improvement in mental balance score comparing between Telmisartan and Cilnidipine. Our results were not consistent with the previous study done by Kavitha et al [20]. In this study more number of subjects were above 60 years and sample size was 104 and duration of treatment was 16 weeks. In our study mean age was 44 years and sample size was 60 only and duration of treatment was 12 weeks. Cilnidipine significantly improved Visual retention score compared to Telmisartan at the end of study. Our results were not consistent with the previous study [20]. In our study, we found that there was no change in cognitive functions as indicated by delayed recall test, immediate recall test, mental balance test, verbal retention of similar pairs, verbal retention of dissimilar pairs and Visual Recognition scores. We observed an improving trend in these scores more in Telmisartan group, though they were not statistically significant. Our results are consistent with the previous studies $[20,30,31]$. A significant improvement was observed in Cilnidipine group when compared to Telmisartan group in six letter cancellation test and Digit Letter Substitution Test. Our results were on accordance with previous studies [20,30]. In the present study, it was observed that hypertension was controlled within 3 months of antihypertensive treatment and no worsening of cognitive functions was observed. Our results were consistent with the previous studies $[20,33]$. There is decrease in the body weight of patients in both the groups at the end of the study. In conclusion, both Telmisartan and Cilnidipine showed no significant change in cognition, but improving trends in these scores and significant improvement in psychomotor functions in patients with newly diagnosed Stage - I essential hypertension. But Telmisartan showed more improving trends in cognitive and psychomotor functions compared to Cilnidipine.Acknowledgements: we thank our faculty in the Dept. of Medicine and our patients, without whom we are unable to complete this study.Conflict of Interest: The authors have no conflicts of interest to declare.Funding: Self-funding.Data availability statement: The data that support the findings of this study are openly available in a public repository that issues datasets with DOIs. reference numbers are given below.

\section{References}

1. Lewington S, Clarke R, Qizilbash N, Peto R, Collins R. Prospective Studies collaboration.

Age specific relevance of usual blood pressure to vascular mortality. A meta-analysis

of individual data for a million adult in 61 prospective studies. Prospective studies

collaboration. The Lancet 2002; 360: 1903 - 13.

2. Ruitenberg A, Skoog I, Ott A, Aevarsson O, Witteman, JC, Lernfelt B, et al. Blood

pressure and risk of dementia: result from the Rotterdam study and the Gothenberg

H-70 study. Dement Geriatric Cogn Disord 2001; 12: 33 - 9.

3. Meyer JS, Rauch GM, Rauch RA, Haque A, Crawford K. Cardiovascular and other risk 
Factors for Alzheimer's disease and vascular dementia. Ann N Y Acad Sci 2000; 903:

$411-23$.

4. B. Sabayan, L. W. Wijsman, J. C. Foster - Dingley et al. Association of visit-to-visit variability in blood pressure with cognitive function in old age: prospective cohort study. BMJ 2013; 347: f4600.

5. N. U. Epstein, K. A. Lane, and M. R. Farlow et al. Cognitive dysfunction and greater visitto-visit systolic blood pressure variability. Journal of the American Geriatrics Society 2013; 61(12): $2168-73$.

6. M. Nagai, S. Hoshide, M. Nishikawa, S. Masahisa, and K. Kario. Visit-to-visit blood pressure variability in the elderly: Associations with cognitive impairment and carotid artery remodelling. Atherosclerosis 2014; 233(1): 19 - 26.

7. Jawed RA. Midlife hypertension is associated with impaired cognition and dementia later. Clev Clin J Med 2002; 69: 664 - 9.

8. B. A. In`t Veld, A. Ruitenberg, A. Hofman, B. H. C. Stricker, M. M. B. Breteler. Antihypertensive drugs and incidence of dementia: The Rotterdam Study. Neurobiology of Aging 2001; 22(3): 407 - 12.

9. P. J. Tully, J.F. Dartigues, S. Debette, C. Helmer, S. Artero, C. Tzourio. Dementia risk with antihypertensive use and blood pressure variability. Neurology 2016; 87(6):

$601-8$.

10. S. Yasar, J. Xia, W. Yao et al. Antihypertensive drugs decrease risk of Alzheimer disease: Ginkgo Evaluation of Memory Study. Neurology 2013; 81(10): 896 - 903.

11. R. Stewart, Q. Xue, K. Masaki et al. Change in Blood Pressure and Incident Dementia: A 32-Year Prospective Study. Hypertension 2009; 54(2): 233 - 40.

12. B. Haring, C. Wu, L. H. Coker et al. Hypertension, Dietary Sodium and Cognitive decline:

Results from the Women's Health Initiative Memory Study. American Journal of Hypertension 2016; 29(2): $202-16$.

13. James PA, Oparil S, Carter BL, Cushman WC, Dennison-Himmelfarb C, Handler J, Lackland DT, LeFevre ML, MacKenzie TD, Ogedegbe O, Smith SC. 2014 evidence based guideline for the management of high blood pressure in adults: report from the panel members appointed to the Eighth Joint National Committee (JNC 8).

JAMA 2014; 311(5): 507 - 20.

14. Forette F., Seux M.-L., Staessen J. A., et al. The prevention of dementia with anti hypertensive treatment: new evidence from the systolic hypertension in Europe (Syst Eur) study. Archives of Internal Medicine 2002; 162(18): 2046 - 52. 
15. Fournier A, Oprisiu-Fournier R, Serot JM, Godefroy O, Achard JM, Faure S, Mazouz H, Temmar M, Albu A, Bordet R, Hanon O, Gueyffier F, Wang J, Black S, Sato N. prevention of Dementia by Antihypertensive Drugs: How AT1-receptor-blockers and Dihydro - pyridines Better Prevent Dementia in Hypertensive Patients than Thiazides and

ACE-inhibitors. Expert Rev Neurother 2009; 9(9): 1413 - 31. PMID: 19769454.

16. Jean K.Ho, Daniel A Nation \& for the Alzheimer's Disease Neuroimaging Initiative.

Memory is preserved in older adults taking AT1 receptor Blockers. Alzheimer's

Research \& Therapy 2017; 9: 33. DOI 10.1186/s13195-017-0255-9.

17. Bulpitt CJ, Fletcher AE. Cognitive function and angiotensin-converting enzyme

inhibitors in comparison with other antihypertensive drugs. J Cardiovasc Pharmacol

1992; 19(Suppl 6): S100 - 04.

18. Efimova IY, Efimova NY, Triss SV, Lishmanov YB. Brain perfusion and cognitive function changes in hypertensive patients. Hypertens Res 2008; 31: 673 - 78.

19. Ekta Arora, Vijay Khajuria, Vishal R. Tandon, Atul Sharma, Naiyma Choudhary.

Comparative evaluation of aliskiren, ramipril, and losartan on psychomotor

performance in healthy volunteers: A preliminary report. Perspectives in Clinical

Research 2014; 5(4): 190 - 94.

20. KavitaRathore, Sunil Kumar Mathur Comparative Study of two ARBs on Memory and

Psychomotor Functions in Mild to Moderate Hypertension. IJSR 2016; 5(9): 531 - 33.

21. Puram NN, Karande VB, Ramanand JB, Ramanand SJ, Halasawadekar NR, Bhosale RR.

Comparison of efficacy of telmisartan with losartan in patients of essential

hypertension with cognitive impairment. Int J Basic Clin Pharmacol 2016; 5: 702 - 6.

22. KavitaRathore, Sunil Kumar Mathur. Comparative Study of Telmisartan Alone and With Atorvastatin On Cognitive Functions in Mild to Moderate Hypertensive Patients.

Indian Journal of Applied Research (IJAR) 2016; 6(9): 647 - 50.

23. C. Bachmeier, D. Beaulieu-Abdelahad, M. Mullan, D. Paris. Selective dihydropyiridine compounds facilitate the clearance of beta-amyloid across the blood-brain barrier.

Eur. J. Pharmacol 2011; 659: 124 - 29.

24. S. Lesné, T. K. Ming, L. Kotilinek et al. A specific amyloid- $\beta$ protein assembly in the brain impairs memory. Nature 2006; 440 (7082): 352 - 357.

25. V Nimmrich, A Eckert. Calcium channel blockers and dementia. British Journal of Pharmacology (BJP) 2013; 169: 1203 - 10.

26. Salomone S, Caraci F, Leggio GM, Fedotova J, Drago F. New pharmacological strategies for treatment of Alzheimer's disease: focus on disease modifying drugs. Br J Clin Pharmacol 2012; 73: 504 - 17. 
27. Mukesh Madhukar Shete. Cilnidipine: Next Generation Calcium Channel Blocker.

J Assoc Physicians India 2016; 64(4): 95 - 99.

28. Pershad D, Wig NN. A battery of simple tests of memory for use in India. Neurol India 1976; 24: 86 - 93. [PubMed: 1012437]

29. Pershad D, Wig NN. Relationship between PGI Memory scale and WAIS verbal I.Q.

Neurol India 1979; 27: 69 - 72.

30. R Fogari, A Mugellini, A Zoppi, G Derosa, C Pasotti, E Fogari and P Preti. Influence of losartan and atenolol on memory function in very elderly hypertensive patients.

Journal of Human Hypertension 2003; 17: 781 - 785.

31. Gore PN, Badar VA, Hardas MM, Bansode VJ, Navale SB. Comparative effects of

Telmisartan and Lisinopril on cognitive function in metabolic syndrome patients.

Int J Clin Exp Physiol 2014; 1: 216 - 20.

32. M Stuhec, J Keuschler, J Serra-Mestres, M Isetta. Effects of Different Antihypertensive

Medication Groups on Cognitive Function in Older Patients: A Systematic Review.

Eur Psychiatry 2017; 46: 1 - 15.

33. Ashok Jaiswal, V. Bhavsar, Jaykaran, N. D. Kantharia. Effect of antihypertensive therapy on cognitive functions of patients with hypertension. Ann Indian Acad

Neurol 2010; 13(3): 180 - 183.

Tables

Table - 1 Baseline demographic characteristics of patients

\begin{tabular}{llll}
\hline Sl. No & Parameter & $\begin{array}{l}\text { Telmisartan group } \\
(\mathrm{n}=30)\end{array}$ & $\begin{array}{l}\text { Cilnidipine group } \\
(\mathrm{n}=30)\end{array}$ \\
\hline 1 & Males (\%) & 73.33 & 66.66 \\
2 & Females (\%) & 26.66 & 33.33 \\
3 & Age in Years & $44.33 \pm 5.36$ & $45.93 \pm 5.03$ \\
4 & Body Weight $(\mathrm{Kgs})$ & $73.80 \pm 5.07$ & $72.93 \pm 4.11$ \\
5 & Height $(\mathrm{cm})$ & $165.02 \pm 3.25$ & $166.86 \pm 4.43$ \\
6 & BMI $\left(\mathrm{Kg} / \mathrm{m}^{2}\right)$ & $27.04 \pm 1.43$ & $26.22 \pm 1.49$ \\
\hline
\end{tabular}

Table - 2 Memory scores in the study groups

\begin{tabular}{|c|c|c|c|c|c|c|c|}
\hline S No & Test & $\begin{array}{l}\text { Telmisartan } \\
\text { Group } \\
\text { Scores (n } \\
=30)\end{array}$ & $\begin{array}{l}\text { Telmisartan } \\
\text { Group } \\
\text { Scores (n } \\
=30)\end{array}$ & $\begin{array}{l}\text { Telmisartan } \\
\text { Group } \\
\text { Scores (n } \\
=30)\end{array}$ & $\begin{array}{l}\text { Cilnidipine } \\
\text { Group } \\
\text { Scores } \quad(\mathrm{n} \\
=30)\end{array}$ & $\begin{array}{l}\text { Cilnidipine } \\
\text { Group } \\
\text { Scores } \quad(\mathrm{n} \\
=30)\end{array}$ & $\begin{array}{l}\text { Cilnidipine } \\
\text { Group } \\
\text { Scores }(\mathrm{n} \\
=30)\end{array}$ \\
\hline & & Baseline & $\begin{array}{l}\text { At } 3 \\
\text { months }\end{array}$ & $P$ value & Baseline & $\begin{array}{l}\text { At } 3 \\
\text { months }\end{array}$ & $P$ value \\
\hline 1 & $\begin{array}{l}\text { Remote } \\
\text { Memory }\end{array}$ & $6.06 \pm 0.70$ & $6.53 \pm 0.51$ & $\mathrm{P}=0.03 *$ & $6.33 \pm 0.61$ & $6.66 \pm 0.48$ & $\mathrm{P}=0.05$ \\
\hline
\end{tabular}




\begin{tabular}{|c|c|c|c|c|c|c|c|}
\hline S No & Test & $\begin{array}{l}\text { Telmisartan } \\
\text { Group } \\
\text { Scores }(\mathrm{n} \\
=30)\end{array}$ & $\begin{array}{l}\text { Telmisartan } \\
\text { Group } \\
\text { Scores }(\mathrm{n} \\
=30)\end{array}$ & $\begin{array}{l}\text { Telmisartan } \\
\text { Group } \\
\text { Scores }(\mathrm{n} \\
=30)\end{array}$ & $\begin{array}{l}\text { Cilnidipine } \\
\text { Group } \\
\text { Scores }(\mathbf{n} \\
=30)\end{array}$ & $\begin{array}{l}\text { Cilnidipine } \\
\text { Group } \\
\text { Scores }(\mathbf{n} \\
=30)\end{array}$ & $\begin{array}{l}\text { Cilnidipine } \\
\text { Group } \\
\text { Scores }(\mathbf{n} \\
=30)\end{array}$ \\
\hline 2 & $\begin{array}{l}\text { Recent } \\
\text { Memory }\end{array}$ & $4.40 \pm 0.50$ & $4.66 \pm 0.48$ & $\mathrm{P}=0.04^{*}$ & $4.60 \pm 0.63$ & $4.73 \pm 0.50$ & $\mathrm{P}=0.16$ \\
\hline 3 & $\begin{array}{l}\text { Mental } \\
\text { Balance }\end{array}$ & $\begin{array}{l}6.06 \pm \\
0.59\end{array}$ & $\begin{array}{l}6.26 \pm \\
0.45\end{array}$ & $\mathrm{P}=0.33$ & $\begin{array}{l}5.73 \pm \\
0.45\end{array}$ & $5.80 \pm 0.56$ & $\mathrm{P}=0.67$ \\
\hline 4 & $\begin{array}{l}\text { Attention } \\
\text { and Con- } \\
\text { centration }\end{array}$ & $14.73 \pm 0.79$ & $15.46 \pm 0.99$ & $\mathrm{P}=0.02 *$ & $15.0 \pm 0.75$ & $15.73 \pm 0.70$ & $\mathrm{P}=0.04^{*}$ \\
\hline 5 & $\begin{array}{l}\text { Visual } \\
\text { Retention }\end{array}$ & $7.80 \pm 0.67$ & $7.66 \pm 0.70$ & $\mathrm{P}=0.54$ & $8.13 \pm 0.63$ & $8.20 \pm 0.56$ & $\mathrm{P}=0.79 \#$ \\
\hline 6 & $\begin{array}{l}\text { Delayed } \\
\text { Recall }\end{array}$ & $\begin{array}{l}6.53 \pm \\
0.51\end{array}$ & $\begin{array}{l}6.73 \pm \\
0.59\end{array}$ & $\mathrm{P}=0.05$ & $\begin{array}{l}6.33 \pm \\
0.48\end{array}$ & $\begin{array}{l}6.80 \pm \\
0.56\end{array}$ & $\mathrm{P}=0.10$ \\
\hline 7 & $\begin{array}{l}\text { Immediate } \\
\text { Recall }\end{array}$ & $7.0 \pm 0.65$ & $\begin{array}{l}7.33 \pm \\
0.48\end{array}$ & $\mathrm{P}=0.05$ & $\begin{array}{l}6.73 \pm \\
0.70\end{array}$ & $\begin{array}{l}6.73 \pm \\
0.70\end{array}$ & $\mathrm{P}=0.09$ \\
\hline 8 & $\begin{array}{l}\text { verbal } \\
\text { retention } \\
\text { of similar } \\
\text { pairs }\end{array}$ & $\begin{array}{l}3.73 \pm \\
0.59\end{array}$ & $\begin{array}{l}3.73 \pm \\
0.59\end{array}$ & $\mathrm{P}=0.09$ & $\begin{array}{l}3.73 \pm \\
0.70\end{array}$ & $\begin{array}{l}3.80 \pm \\
0.77\end{array}$ & $\mathrm{P}=0.09$ \\
\hline 9 & $\begin{array}{l}\text { verbal } \\
\text { retention } \\
\text { of } \\
\text { dissimilar } \\
\text { pairs }\end{array}$ & $\begin{array}{l}7.53 \pm \\
0.59\end{array}$ & $\begin{array}{l}7.73 \pm \\
0.70\end{array}$ & $\mathrm{P}=0.05$ & $\begin{array}{l}7.93 \pm \\
0.70\end{array}$ & $\begin{array}{l}8.06 \pm \\
0.59\end{array}$ & $\mathrm{P}=0.09$ \\
\hline 10 & $\begin{array}{l}\text { Visual } \\
\text { Recognition }\end{array}$ & $\begin{array}{l}7.53 \pm \\
0.51 \\
\end{array}$ & $\begin{array}{l}7.80 \pm \\
0.67 \\
\end{array}$ & $\mathrm{P}=0.16$ & $\begin{array}{l}7.20 \pm \\
0.67\end{array}$ & $\begin{array}{l}7.40 \pm \\
0.50 \\
\end{array}$ & $\mathrm{P}=0.18$ \\
\hline \multicolumn{8}{|c|}{$\begin{array}{l}{ }^{*} \mathrm{P}<0.05 \text { within the group compared to baseline. } \\
\# \quad \mathrm{P}<0.05 \text { compared between the study groups. } \\
\text { Table }-\mathbf{3} \quad \text { Psychomotor function tests }\end{array}$} \\
\hline \multirow[t]{2}{*}{ S No } & Test & $\begin{array}{l}\text { Telmisartan } \\
\text { Group } \\
\text { Scores }(\mathbf{n} \\
=30)\end{array}$ & $\begin{array}{l}\text { Telmisartan } \\
\text { Group } \\
\text { Scores }(\mathbf{n} \\
=30)\end{array}$ & $\begin{array}{l}\text { Telmisartan } \\
\text { Group } \\
\text { Scores }(\mathbf{n} \\
=30)\end{array}$ & $\begin{array}{l}\text { Cilnidipine } \\
\text { Group } \\
\text { Scores }(\mathbf{n} \\
=30)\end{array}$ & $\begin{array}{l}\text { Cilnidipine } \\
\text { Group } \\
\text { Scores } \quad(\mathbf{n} \\
=30)\end{array}$ & $\begin{array}{l}\text { Cilnidipine } \\
\text { Group } \\
\text { Scores }(\mathrm{n} \\
=30)\end{array}$ \\
\hline & & Baseline & $\begin{array}{l}\text { At } 3 \\
\text { months }\end{array}$ & $\mathbf{P}$ value & Baseline & $\begin{array}{l}\text { At } 3 \\
\text { months }\end{array}$ & $P$ value \\
\hline 1 & $\begin{array}{l}\text { Six letter } \\
\text { cancellation } \\
\text { test }\end{array}$ & $36.73 \pm 1.83$ & $38.80 \pm 1.56$ & $\mathrm{p}<0.01 \$$ & $37.20 \pm 1.93$ & $40.33 \pm 1.58$ & $\begin{array}{l}\mathrm{p}<0.01 \\
\$ \#\end{array}$ \\
\hline 2 & $\begin{array}{l}\text { Digit Letter } \\
\text { Substitution } \\
\text { Test }\end{array}$ & $39.66 \pm 1.63$ & $40.06 \pm 1.57$ & $\mathrm{P}=0.16$ & $40.46 \pm 1.59$ & $41.20 \pm 1.26$ & $\mathrm{P}=0.05 *$ \\
\hline 3 & $\begin{array}{l}\text { Card sorting } \\
\text { test }\end{array}$ & $82.13 \pm 2.47$ & $76.60 \pm 3.43$ & $\mathrm{p}<0.01 \$$ & $83.73 \pm 3.76$ & $79.06 \pm 2.82$ & $\mathrm{p}<0.01 \$$ \\
\hline
\end{tabular}


$\$$ - $\mathrm{P}<0.01$ within the group compared to baseline.

* $\mathrm{P}<0.05$ compared between the groups at the end of study.

\# $-\mathrm{P}<0.01$ compared between the groups at the end of study.

Table - 4 Effect on Secondary Outcomes

\begin{tabular}{|c|c|c|c|c|c|c|c|}
\hline S No & Test & $\begin{array}{l}\text { Telmisartan } \\
\text { Group } \\
\text { Scores (n } \\
=30)\end{array}$ & $\begin{array}{l}\text { Telmisartan } \\
\text { Group } \\
\text { Scores }(\mathrm{n} \\
=30)\end{array}$ & $\begin{array}{l}\text { Telmisartan } \\
\text { Group } \\
\text { Scores ( } \mathrm{n} \\
=30)\end{array}$ & $\begin{array}{l}\text { Cilnidipine } \\
\text { Group } \\
\text { Scores } \quad(\mathrm{n} \\
=30)\end{array}$ & $\begin{array}{l}\text { Cilnidipine } \\
\text { Group } \\
\text { Scores (n } \\
=30)\end{array}$ & $\begin{array}{l}\text { Cilnidipine } \\
\text { Group } \\
\text { Scores (n } \\
=30)\end{array}$ \\
\hline & & Baseline & $\begin{array}{l}\text { At } 3 \\
\text { months }\end{array}$ & $\mathbf{P}$ value & Baseline & $\begin{array}{l}\text { At } 3 \\
\text { months }\end{array}$ & $P$ value \\
\hline 1 & Systolic BP & $\begin{array}{l}144.53 \pm \\
2.32\end{array}$ & $\begin{array}{l}130.13 \pm \\
3.33\end{array}$ & $\mathrm{p}<0.01 \$$ & $\begin{array}{l}143.20 \pm \\
1.97\end{array}$ & $128.0 \pm 2.82$ & $\mathrm{p}<0.01 \$$ \\
\hline 2 & Diastolic BP & $86.26 \pm 2.60$ & $80.66 \pm 1.95$ & $\mathrm{p}<0.01 \$$ & $86.93 \pm 3.45$ & $82.40 \pm 1.35$ & $\begin{array}{l}\mathrm{p}<0.01 \\
\$ \#\end{array}$ \\
\hline 3 & $\begin{array}{l}\text { Body } \\
\text { Weight }\end{array}$ & $73.80 \pm 5.07$ & $72.73 \pm 3.71$ & $\mathrm{P}<0.05 \$$ & $72.93 \pm 4.11$ & $72.0 \pm 3.44$ & $\mathrm{p}<0.01 \$$ \\
\hline
\end{tabular}

$\$$ - $\mathrm{P}<0.01$ within the group compared to baseline.

\# $-\mathrm{P}<0.01$ compared between the groups at the end of study.

\section{Hosted file}

Figures.docx available at https: //authorea.com/users/315467/articles/445856-the-effect-of-telmisartanversus-cilnidipine-on-memory-and-psychomotor-functions-in-patients-with-essential-hypertensionan-open-label-randomized-parallel-comparative-study 